\title{
A Közel-Kelet nukleáris kérdései - középpontban az iráni nukleáris program
}

\author{
Nuclear Issues in the Middle East \\ with Focus on the Iranian Nuclear Program
}

N. Rózsa Erzsébel

https://doi.org/10.47707/Kulugyi_Szemle.2021.3.5

Összefoglaló: A Közel-Kelet a nukleáris energia felhasználásának mindkét dimenziójában - a civil/békés és a katonai célú alkalmazása kapcsán - a világ egyik legtöbb kihívást támasztó térsége. Ezen belül az 1990-es években elsősorban még Irak, a 2000-es években azonban már Irán, az iráni nukleáris program váltja ki a nemzetközi közösség figyelmét és kényszerítő lépéseit. A jelen tanulmány arra tesz kísérletet, hogy a Közel-Kelet nukleáris kérdéseit összefoglalja, és abban az iráni nukleáris programot elhelyezze.

Kulcsszavak: Irán, Amerikai Egyesült Államok, nukleáris energia, proliferáció, nukleáris megállapodás

Abstract: The Middle East is among the regions of the world posing the most challenges in both - the civilian and the military - dimensions of the use of nuclear energy. While in the 1990's it was Iraq, in the 2000's it has been Iran and the Iranian nuclear program demanding the attention of the international communily and inilialing joint action. The present arlicle aims at summarizing the nuclear issues relevant in the Middle East and to put the Iranian nuclear program in context.

Keywords: Iran, Uniled States of America, nuclear energy, proliferation, nuclear deal 


\section{Nukleáris energia és atomsorompó}

A nukleáris energia - és az előállítására irányuló folyamat, az ún. nukleáris fútőanyagkör - önmagában kettős felhasználású, azaz az abban „részt vevő” anyagok, berendezések és technológiák mind civil, mind katonai célra felhasználhatók. Ezért az alkalmazása során az érintett államok politikai szándékának - hiszen az elő́llítás képességét nem állami szereplő eddig nem tudta elsajátítani - kiemelkedô jelentősége van.

A nukleáris energiával kapcsolatos kutatások a 19. századba nyúlnak vissza, azonban a birtoklásához és alkalmazásához való tudás és képesség egyértelműen a 20. században alakult ki. Ismert, hogy az első atomfegyvereket ${ }^{1}$ a második világháború alatt az Amerikai Egyesült Államok állította elő, és az országhoz füződik a nukleáris fegyverek máig egyetlen (bár két alkalommal - Hirosima és Nagaszaki ellen - történt) bevetése is. Miközben az USA megpróbálta megőrizni az atomfegyverek monopóliumát, a világháborút követő években több államnak is sikerüilt kifejlesztenie a képességet: a Szovjetunió 1949ben, az Egyesüllt Királyság 1952-ben, Franciaország 1960-ban, a Kínai Népköztársaság pedig 1964-ben robbantotta fel az elsô nukleáris robbanószerkezetét. Ezzel párhuzamosan a nukleáris technológiának és tudásnak a civil felhasználású terjedését sem lehetett megállítani, miközben az ilyen fegyverek további elterjedésének a megakadályozása - a nukleáris fegyverképességgel rendelkező államok számának növekedésével - még fontosabbá vált. Ezért 1953-ban Dwight D. Eisenhower amerikai elnök meghirdette az „atomot békéért” programot, amely révén civil célú nukleáris együttmúködést ajánlott fel mindazoknak, akik cserében lemondtak a nukleáris energia katonai célú alkalmazásának opciójáról. Az akkor meghirdetett alapelvek szerint ne legyen a világban több, nukleáris fegyverképességgel rendelkező állam, és a birtoklásáról való lemondás fejében szabad hozzáférést

1 Az atomfegyver kifejezést általában a nukleáris fegyverek elsỏ generációja, az atommag-hasadáson alapuló fegyverek megjelölésére használták. Az atommagok fúzióján alapuló fegyverek megjelenése után a mindkettőt magában foglaló megnevezés a nukleáris fegyver lett. 


\section{Külïgyi Szemle}

kell biztosítani az energia e típusának a békés célú felhasználásához. Ugyanezek az eszmék jelentek meg az 1968-ban aláirásra megnyitott atomsorompó-szerződésben (Nuclear Non-Proliferation Treaty, NPT) is, és egészuiltek ki a verifikációval, azaz a szerződés betartásának a nemzetközi ellenőrzésével.

A nukleáris fegyverek hasznáról, használhatóságáról máig tartó vita zajlik. Annak ellenére, hogy a hidegháborús tapasztalatok alap ján az elrettentő képesség tűnik a legfontosabb előnyének, tagad hatatlanul szerepet játszott az alkalmazásában a presztízs, a mo dernség, a technikai fejlettség percepciója is - pedig ez utóbbiakat a nukleáris energia békés célú felhasználásának a képessége is tudja nyújtani. Ötvenhárom évvel a szerződés aláirásra megnyitása után azt mondhatjuk, hogy az atomsorompó minden hiányossága ellenére jól működött/működik: a nukleáris fegyverekkel rendelkezỏ államok száma „mindössze” néggyel nőtt (India, Pakisztán, Észak-Korea és Izrael) - az atomhatalmi státuszukat ${ }^{2}$ azonban a nemzetközi jog nem ismeri el. Habár az atomsorompó-szerződésben rögzített atomhatalmak (az Egyesült Államok, a Szovjetunió/Oroszország, az Egyesült Királyság, Franciaország és Kína) máig sem szerelték le a nukleáris arzenáljukat - amire pedig az egyezmény preambuluma és 6. cikke késztetné óket -, a világ többi állama mára az NPT atomfegyverrel nem rendelkező státuszú részesei (kivételt jelent India, Pakisztán, Izrael és Észak-Korea).

Ugyanakkor a nukleáris energia békés célú felhasználása (anyagok, berendezések, technológiák), illetve annak talán a leglátványosabb megjelenési formája, az atomerőmú (azaz a villamosáram-termelés), számos országban megjelent. Ma a világ 34 országában, összesen 442 atomerőművi blokk üzemel (ez a világ áramszolgáltatásának mintegy 11 százalékát adja), s további 51 építése folyik, 67 reaktor pedig terve zés alatt áll (International Atomic Energy Agency, 2021).

2 Az atomsorompó-szerződés értelmében atomhatalom az az állam, amely 1967. január 1. előtt nukleáris robbanószerkezetet állított elő és robbantott fel. 


\section{Nukleáris energia és atomsorompó a Közel-Keleten}

Ma a Közel-Kelet minden állama - Izrael kivételével - atomfegyverrel nem rendelkező országként részese az atomsorompó-szerződésnek. Ugyanakkor közülüik több is megpróbálkozott valamilyen módon nuk leáris fegyverekhez jutni, elsősorban a regionális hatalmi egyensúly és elrettentés okán, hiszen ez a képesség akár a rezsim túlélésének a biztositéka is lehetne, azonban máig Izrael a térség egyetlen állama, amely nukleáris arzenállal rendelkezik. ${ }^{3}$ A Közel-Kelet nukleáris „térképe” azonban ennél sokkal összetettebb képet mutat. Egyrészt a térség ún. „penetrated region” (Csicsmann, N. Rózsa és Szalai, 2017), azaz a küilsô hatalmak - elsősorban az Amerikai Egyesüllt Államok, de akár más atomhatalmak is - meghatározó szerepet játszanak, többjük állandó katonai jelenléttel rendelkezik, különösen a Perzsa-öböl arab államaiban. Törökországban, amelyet gyakran sorolnak a KözelKelethez, bár több szempontból a térségen kíviul helyezkedik el, az amerikaiak telepítettek nukleáris fegyvereket. Másrészt a régió köz vetlen szomszédságában nukleáris arzenállal rendelkezô államok is találhatók: Oroszország, Pakisztán, India. Így a Közel-Kelet a nukleáris fegyverkezés, illetve a fegyverzetellenőrzés szempontjából kiemelt nemzetközi figyelmet követel magának. Különösen akkor, amikor az egyik vagy másik államát az a gyanú éri, hogy maga is nukleáris fegyverek megszerzésére törekszik.

A Közel-Kelet atomfegyvermentes övezetté nyilvánítása ezért (is) időről időre megjelenik a nemzetközi napirenden. Bár a javas latot először az iráni delegáció terjesztette elő, 1974-ben, a 2010 es atomsorompó-konferencián fogalmazódott meg, hogy a témáról 2012-re nemzetközi konferenciát hívjanak össze. Annak ellenére, hogy jelentős diplomáciai tevékenység indult meg, ${ }^{4}$ azt végüil bi zonytalan időre elnapolták, és az övezet terve máig nem valósult

3 Izrael soha nem deklarálta a (katonai) nukleáris képességét; közvetett bizonyítékok alapján azonban a nemzetközi közösség tényként kezeli annak meglétét.

4 A konferencia facilitatorának, a finn diplomata Jaakko Laajavának a munkáját se gítették az Academic Peace Orchestra Middle East nevű kutatócsoport által ké szitett tanulmányok (Academic Peace Orchestra Middle East, 2016). 


\section{Külïgyi Szemle}

meg.5 A közel-keleti atomfegyvermentes övezet (N. Rózsa és Péczeli, 2013a) létrehozásának elhúzódása, a bizonytalan ideig történő kito lódása többek között a nemzetközi környezet folyamatos változásá val indokolható. Ráadásul a tömegpusztító fegyverekkel és az azokat célba juttató eszközökkel kapcsolatban a térségben az aszimmetrikus viszonyok átláthatatlan rendszere alakult ki (N. Rózsa, 2018) - részben éppen a nukleáris fegyverek elérhetetlensége okán. Arab ország máig sem jutott a képesség közelébe, közülüik azonban többen (Egyiptom, Irak, Szíria, Líbia) - talán épp ezért - vegyi és biológiai fegyverprog ramokba kezdtek. Céljuk az izraeli nukleáris képességgel szemben va lamiféle egyensúly kialakítása volt - de a zsidó állam is rendelkezett ilyen programokkal. Sőt, a vegyi fegyverekkel nem állami radikális mi litáns szervezetek is próbálkoztak. Ezt a feltételességet kívánta meg szüntetni Mohamed Hoszni Mubárak egyiptomi elnök, amikor 1981 ben javasolta a Közel-Kelet minden tömegpusztító fegyvertől mentes övezetté nyilvánítását.

A 2000-es évekig a tömegpusztító fegyverek megszerzésére irányuló arab törekvések középpontjában deklaráltan az izraeli nukleáris képesség ellensúlyozása állt, és ezt célozta Amr Múszának, az Arab Liga főtitkárának a 2007-es felszólítása is, hogy minden arab tagállam kezdjen (civil célú) nukleáris programba. 2002-től azonban, amikor is az iráni nukleáris program előre be nem jelentett építkezéseire fény derült, a Perzsa-öböl arab államai számára egy esetleges iráni nukleáris fenyegetés vált az elsődlegessé, miközben a Földközi-tenger keleti medencéjében - legalábbis a politikai retorika szintjén - továbbra is fennállt az izraeli fenyegetés elsődlegessége. (Mindeközben a koráb ban is többnyire csak névleges és eseti arab összetartás egyre gyen gült, ami a Maghreb országainak az egyre csökkenő érdekeltségét mutatta mind az izraeli, mind az iráni nukleáris program tekintetében.) Mindezek ellenére a Közel-Kelet országai a tömegpusztító fegyvereket korlátozó multilaterális szerződések többségéhez csatlakoztak. ${ }^{6}$

5 Meg kell jegyezni, hogy Törökország sem a közel-keleti atomfegyvermentes-, sem a tömegpusztítófegyver-mentes övezet terveiben nem szerepel részes államként.

6 A jelen tanulmány kereteit meghaladja annak elemzése, hogy melyik ország miért nem csatlakozott egyik vagy másik szerződéshez. Bővebben: N. Rózsa és Péczeli. 2013b. 


\section{1. táblázat}

\section{A közel-keleti államok státusza a tömegpusztító fegyvereket korlátozó}

multilaterális szerződésekben ${ }^{7}$

\begin{tabular}{|c|c|c|c|c|c|c|c|}
\hline & $\begin{array}{l}\text { Atom- } \\
\text { sorompó- } \\
\text { szerzódés } \\
\text { (NPT) }\end{array}$ & \begin{tabular}{|c|} 
Átfogó \\
atomesend- \\
szerződés \\
(CTBT)
\end{tabular} & $\begin{array}{c}\text { Genfi } \\
\text { jegyző- } \\
\text { könyv } \\
\text { (Geneva } \\
\text { Protocol) }\end{array}$ & $\begin{array}{l}\text { Vegyi- } \\
\text { fegyver- } \\
\text { tilalmi } \\
\text { megálla- } \\
\text { podás } \\
\text { (CWC) } \\
\end{array}$ & $\begin{array}{c}\text { Biológiai- } \\
\text { és } \\
\text { toxinfegyver- } \\
\text { tilalmi } \\
\text { megállapodás } \\
\text { (BTWC) }\end{array}$ & $\begin{array}{l}\text { Hágai } \\
\text { maga- } \\
\text { tartási } \\
\text { kódex } \\
\text { (Hague } \\
\text { CoC) } \\
\end{array}$ & \begin{tabular}{|l} 
Rakéta- \\
techno- \\
lógiai \\
ellenőrzési \\
rendszer \\
(MTCR) \\
\end{tabular} \\
\hline Algéria & 1995 & $1996 / 2003$ & 1992 & 1993/1995 & 2001 & & \\
\hline Bahrein & 1998 & $1996 / 2004$ & 1988 & $1993 / 1997$ & 1988 & & \\
\hline $\begin{array}{l}\text { Egyesült Arab } \\
\text { Emírségek }\end{array}$ & 1995 & $1996 / 2000$ & & $1993 / 2000$ & $1972 / 2008$ & & \\
\hline Egyiptom & $1968 / 1981$ & 1996 & $1925 / 1928$ & & 1972 & & \\
\hline Irak & $1968 / 1969$ & $2008 / 2013$ & 1931 & 2009 & $1972 / 1991$ & 2002 & \\
\hline Irán & $1968 / 1970$ & 1996 & 1929 & 1993/1997 & $1972 / 1973$ & & \\
\hline Izrael & & 1996 & 1969 & 1993 & & & \\
\hline Jemen & $1968 / 1986$ & 1996 & 1971 & $1993 / 2000$ & $1972 / 1979$ & & \\
\hline Jordánia & $1968 / 1970$ & $1996 / 1998$ & 1977 & 1997 & $1972 / 1975$ & 2002 & \\
\hline Katar & 1989 & $1996 / 1997$ & 1976 & $1993 / 1997$ & $1972 / 1975$ & & \\
\hline Kuvait & $1968 / 1989$ & $1996 / 2003$ & 1971 & $1993 / 1997$ & $1972 / 1972$ & & \\
\hline Libanon & $1968 / 1970$ & $2005 / 2008$ & 1969 & 2008 & $1972 / 1975$ & & \\
\hline Líbia & $1968 / 1975$ & $2001 / 2004$ & 1971 & 2004 & 1982 & 2002 & \\
\hline Marokkó & $1968 / 1970$ & $1996 / 2000$ & 1970 & $1993 / 1995$ & $1972 / 2002$ & 2002 & \\
\hline Mauritánia & 1993 & $1996 / 2003$ & & $1993 / 1998$ & & & \\
\hline Omán & 1997 & 1990/2001 & & $1993 / 1998$ & 1992 & & \\
\hline Szaúd-Arábia & 1988 & & 1971 & 1993/1996 & $1972 / 1972$ & & \\
\hline Szíria & $1968 / 1969$ & & 1968 & $2013^{*}$ & 1972 & & \\
\hline Szomália & $1968 / 1970$ & & & 2013 & 1972 & & \\
\hline Szudán & $1968 / 1973$ & $2004 / 2004$ & 1980 & 1999 & 2003 & & \\
\hline Törökország & $1969 / 1980$ & 1996/2000 & 1929 & \begin{tabular}{|l|}
$1993 / 1997$ \\
\end{tabular} & $1972 / 1974$ & 2002 & \\
\hline Tunézia & $1968 / 1970$ & 1996/2004 & 1967 & 1993/1997 & $1972 / 1973$ & 2002 & \\
\hline
\end{tabular}

7 A „/" jellel elválasztott két dátum (pl. 1972/2008) az aláírás és a ratifikáció időpontját jelzi. A vastagon szedett számjegyek az aláirás meglétét, de a ratifikáció hiányát jelölik. Az egyes tömegpusztító fegyvereket korlátozó szerződésekkel kap csolatban ld. N. Rózsa és Péczeli, $2013 b$. 


\section{Külïgyi Szemle}

A tömegpusztító fegyvereket célba juttató ballisztikus rakétákról a mai napig nem született olyan átfogó multilaterális megállapodás, mint a tömegpusztító fegyverek egyes kategóriáiban; a térség országai viszont nem hajlandók feladni azok lehetőségét, sôt több állam rendelkezik saját, továbbfejlesztett és/vagy vásárolt rakétákkal, rakétarendszerekkel. Így a sokat emlegetett iráni rakétaprogram semmiképp sem egyedülálló - nem is beszélve a térségen kívüli, de ott katonai bázisokkal rendelkező államokról.

A Közel-Kelet nukleáris „térképét” a civil célú nukleáris programok tovább árnyalják, és ebben a nukleáris technológia, know-how és berendezések térségbeli eladására törekvő külső hatalmak (Oroszország, Dél-Korea, Kína stb.) is szerepet játszanak, sőt akár komolyabb befolyáshoz is juthatnak. A régióban jelenleg két országban működik egy-egy atomerőmủ (atomerőmúvi blokk): Iránban a Búsehr-1-et 2011-ben, az Egyesült Arab Emírségekben a Baraka-1-et 2020-ban kapcsolták az elektromos hálózatra. Iránban egy (Búsehr-2), az Emírségekben három újabb blokk (Baraka-2, -3, -4) épüil. Törökországban egyszerre hármat építenek (Akkuyu-1, - 2, -3). ${ }^{8}$ Bár Amr Músza említett felszólitását követően több ország is jelezte, hogy atomerőmúvek épitését tervezi, azok máig nem léptek a megvalósítás fázisába. Bár az atomerőművek száma egyelőre csekély a térségben, ez tehát nem jelenti azt, hogy egyéb civil célú nukleáris tevékenység ne folyna egyes országokban, hiszen kutató- és tanreaktorok több helyen is múködnek, például orvosi izotópok előállítására, mezőgazdasági célokra stb. (N. Rózsa, 2018).

\section{Az iráni nukleáris program}

A nukleáris energia felhasználásának kettős lehetősége, illetve a már említett állami szándék bonyolult helyzeteket eredményez, amelyekben az objektív tények mellett (pl. milyen létesítménnyel rendelkezik egy állam) olyan, szubjektívnek nevezhető tényezők is közrejátszanak,

8 IAEA PRIS, 2021. Az iráni és a török blokkokat az orosz Roszatom, a Emírségekben a Baraka blokkjait a dél-koreai KEPCO építi. 
mint egy állam biztonsági percepciója vagy a mások által róla alkotott vélemény (pl. megbízható rendszer-e). A nukleáris energiával kapcsolatos kérdésekben ezek a szubjektív tényezők - akár pro, akár contra különös jelentőséggel bírnak.

Az ún. teljes fütőanyagciklussal (azaz az uránérc bányászatától az erőművi felhasználásig, az újrafeldolgozásig és a hulladékelhelyezésig tartó technológiasorral) ugyanis a világ igen csekély számú, mintegy tucatnyi országa rendelkezik. Így azok gyakorlatilag mások „segítsége” nélküil, önállóan dönthetik el, milyen célra használják ezt a képességet. Habár általában azt a mintegy negyven országot is potenciális proliferációs veszélyként szokták megjelölni, amely a nukleáris fütőanyagkörnek csak bizonyos részleteivel rendelkezik (mint pl. Magyarország), a teljes ciklus megléte az, ami - különösen a politikailag „megbízhatatlannak” ítélt országok esetében - a nemzetközi közösség gyanúját kiválthatja. A Közel-Keleten Irán az egyetlen ilyen ország, hiszen Izrael, amely sokkal korábban épített ki igen fejlett nukleáris infrastruktúrát, atomerőmúvel nem rendelkezik.

Így tehát a civil célú nukleáris képesség is komoly presztízst jelent, és fejlett, modern államot sugall, de a kettős felhasználás lehetősége révén még akkor is magában hordoz bizonyos fenyegetést, ha az adott ország, mint Irán, következetesen állítja, hogy a programja kizárólag békés, civil célokat szolgál.

Az iráni nukleáris program a már említett Eisenhower-doktríná hoz köthető: Irán 1956-ban az Egyesült Államoktól vásárolt egy 5 MW teljesítményű, könnyűvizes, magasan dúsított urán üzemanyagú kutatóreaktort (Jones és McDonough, 1998), amely a Teheráni Egyetemen ma is orvosi izotópokat állít elö. Az 1974-es indiai nukleáris kísérleti robbantást követően - több más közel-keleti országhoz hasonlóan - Iránban is ambiciózus nukleáris fejlesztési program kez dődött, amelynek keretében Mohamed Reza Pahlavi sah az ezredfor dulóig húsz atomerőművet akart építtetni. Annak ellenére, hogy Irán 1968-ban aláírta, majd 1970-ben ratifikálta az atomsorompó-szerződést, 1973-ban pedig aláírta a dokumentum szerint készült teljes körű biztosítéki megállapodást a Nemzetközi Atomenergia-ügynökséggel 


\section{Külïgyi Szemle}

(NAÜ), amely 1974-ben lépett hatályba, általában azt feltételezik, hogy a sah nukleáris programjának volt egy titkos katonai része is.

1976-ban a Siemens Kraftwerk Union vezetésével egy nemzetkö zi konzorcium kezdte meg az első iráni atomerőmú építését, amit azonban az 1979-es iszlám forradalom győzelme után Ruholláh Kho meini ajatollah leállított. Az építkezést csak a nyolcvanas évek köze pén kezdték újra, azonban az épüilő blokkokat az iraki-iráni hábo rú (1980-1988) utolsó éveiben találat érte, így a munkálatok ismét leálltak. Ezt követően, illetve az iraki-kuvaiti öbölháború (1991) után az Irakkal szemben elrendelt nemzetközi ellenőrzések tapasztalatai alapján bekövetkezett exportellenőrzési szigorítások miatt az erede ti kivitelező nem tudta folytatni az építkezést. Így - sokéves késés sel és immár orosz közremûködéssel fejezték be az erőmű 1. blokkját (VVER-1000 MW), s azt 2011-ben kapcsolták rá az iráni elektromos hálózatra. A jelenleg építés alatt álló Búsehr-2 blokk (VVER-1000/ V-466B) munkálatai a Roszatommal kötött szerződés alapján 2019 ben kezdődtek, és a tervek szerint 2024-re készülnek el vele (World Nuclear Association, 2021).

A 2000-es évek elején az iráni nukleáris programnak az akkor még csak igen korlátozott technológiai folyamatait és létesítménye it a nemzetközi ellenőrök - az atomsorompó-szerződésben foglal tak, illetve a NAÜ-vel kötött teljes körű biztosítéki megállapodás sze rint - rendszeresen ellenőrizték. Irán akkor még nem rendelkezett sem az urándúsítás, sem egyéb olyan technológiával, amely egy esetleges fegyverprogrammal fenyegethetett volna. Éppen ezért sokkolta a nemzetközi közösséget, amikor 2002-ben kiderült, hogy Irán Natanzban egy urándúsítómúvet, Arakban pedig egy nehézvízgyárat épít. (Ez utóbbi a plutóniumtüzelésű reaktorok múködtetésében játszik szerepet.) A szerződés szerint Iránnak az építkezéseket „minél hamarabb, de legkésőbb 180 nappal az üzembe helyezés előtt” kellett bejelentenie a NAÜ-nek, Teherán ezt csak a határidő leteltekor, s nem korábban tette meg. Bár a betủ szerinti teljesítés nyilván vitatható volt, az országgal szembeni fenntartások - az 1979-es iszlám forradalomig visszavezethetően - azonnal a nemzetközi napirendre helyezték az iráni nukleáris program kérdését. 
Az ezt követő nemzetközi tárgyalásokat az Európai Unió három legnagyobb tagállama, az Egyesüilt Királyság, Franciaország és Németország kezdte meg Iránnal, míg az Egyesült Államok évekig csak a háttérből figyelt. Azonban az első pillanattól kezdve nyilvánvaló volt, hogy bármilyen egyezmény is születik, abban Washington meghatározó szerepet játszik majd, azaz nélküle nem lesz megállapodás.

Az Egyesült Államok az 1979-es iszlám forradalmat követő tehe ráni követségfoglalás és túszejtés óta mélységes gyanakvással viszo nyult az Iszlám Köztársasághoz, közvetlenül semmilyen kapcsolatot nem tartott vele, ,megbízhatatlan rezsimnek”, ,a Gonosz tengelyének” nevezte azt. Az iráni vezetés szemében viszont az USA számított ,a nagy Sátánnak”, Izrael pedig ,a kis Sátánnak”, és olyan nyilatkozatok is elhangzottak, hogy mivel Irán ellenségeinek (az Egyesült Államoknak és Izraelnek) vannak nukleáris fegyverei, hazájuknak is rendelkeznie kell ilyen képességgel. ${ }^{9}$ Mindezt azonban - iráni szempontból elméletileg véglegesen és kategorikusan - kizárta Ali Khamenei ajatollah „nukleáris fatvája”, amely szerint az Iszlám Köztársaságban tilos tömegpusztító fegyverek elóállítása, felhalmozása és használata. Ezt a tényt Irán a különböző diplomáciai fórumokon azóta is hangoztatja. A nukleáris fegyverek tilalmát a fatva elhangzása óta többször is megismételték az iráni vezetők - különösen a nukleáris tárgyalások érzékenyebb szakaszaiban (elsősorban Khamenei ajatollah), de legutóbb a beiktatási beszédében Ebrahim Raiszi elnök is utalt rá (ISNA, 2021). Fóleg a nyugati, de más államokban is komoly vita zajlott/zajlik azonban arról, hogy egy fatva - és különösen ez a fatva - milyen hatállyal bír. Különösen akkor merül fel a kérdés, amikor iráni oldalról olyan fenyegetések hangzanak el, mint hogy „ha Iránt megtámadják, a válasz globális/borzalmas lesz" (Space Daily, 2010) - amit sokan egy esetleges nukleáris csapás veszélyeként értelmeznek. Más vélemények szerint az ilyen kijelentések sokkal inkább az elrettentést szolgálják, és leginkább olyankor hangzottak/hangzanak el, amikor az Irán megtámadásáról szóló katonai tervekről szól a média.

9 Pl.: Mahardzseráni ajatollah és elnökhelyettes szájából (Keesing’s World News Archive, 1991, 38549. o.). 


\section{Külïgyi Szemle}

Mára Irán a teljes nukleáris fútőanyagkörrel rendelkezik - annak ellenére, hogy a nemzetközi közösség súlyos, kötelező érvényú szankciókat hozott az országgal szemben. Mint arra Mohamed Dzsavád Zarif, a hivatalából nemrég távozott külïgyminiszter rendszeresen utalt a beszédeiben, a szankciók eredményességét, pontosabban eredménytelenségét mi sem mutatja jobban, mint az, hogy az ország minden büntetőintézkedés ellenére képes volt a teljes ciklus kiépítésére - természetesen és ismételten civil céllal. A folyamatos fenye getések hatására azonban a különböző fázisokat számtalan helyszínen, szétszórva alakították ki, miközben az álláspontjuk változatlan: a nukleáris energiát az Iszlám Köztársaságban kizárólag békés célokra lehet használni.

\section{Szankciók és a nukleáris megállapodás ${ }^{10}$}

A natanzi és araki nukleáris építkezésről szóló 2002-es bejelentés következményeként meginduló tárgyalások 2015-ben, több megtorpanás, majd az ENSZ Biztonsági Tanácsának (BT) kötelezỏ érvényủ szankciói után, az iráni nukleáris megállapodáshoz, az ún. Közös átfogó cselekvési tervhez (Joint Comprehensive Plan of Action, JCPOA) vezettek.

Az Iránnal szemben kialakult szankciós rezsim egy igen bonyolult rendszer, amely az ideje, a témája, illetve a szankcionáló aktor tekintetében nagyon különböző határozatokból áll. Az ENSZ Biztonsági Tanácsának mindenkire nézve kötelezỏ szankciói mellett az egyes államok elsődleges (a saját joghatóságuk alá tartozó személyeket, cégeket kötelező) és másodlagos (azaz más állampolgárságú személlyel vagy vállalattal szemben is hatályba lépő) szankciókat is hoztak."

1979 őszén, a teheráni amerikai követségen lezajlott túszdrámát követően, az Egyesüllt Államok unilaterális szankciókat foganatosított Iránnal szemben. Bár a következó évtizedekben Washington többféleképp is megpróbálta Iránt elszigetelni (pl. a Clinton-kormány kettős

10 A fejezet a szerző nemrég megjelent tanulmányán alapul. Ld. N. Rózsa, 2021.

11 A szankciók kérdéséről bővebben ld. Csicsmann, 2021. 
feltartóztatási politikájával vagy a többször is meghirdetett rezsimvál tás szándékával), az 1996-os Iráni és líbiai szankciós törvény (2006 tól: Iráni szankciós törvény) alapozta meg a másodlagos szankciók rendszerét, amely szerint azok a küllöldi vállalatok, amelyek 20 millió dollárnál nagyobb összeget fektetnek be az iráni olajszektor fejleszté sébe, a törvényben megszabott büntetésekkel sújthatók.

A Teheránnal 2002 után folytatott tárgyalások, majd azok elakadását követően a nemzetközi közösség által hozott szankciók elsősor ban azt kívánták megakadályozni, hogy Irán elsajátítsa az urándúsítás képességét. Ám mire az ENSZ BT-ben 2006 decemberében az első kötelező szankciót meghozták Iránnal szemben, az - bár csak laboratóriumi körülmények között - már képes volt uránt dúsítani. Az ország nukleáris programja kapcsán az ENSZ BT 2006 és 2010 között hat határozatot hozott, közüilük négy tartalmazott szankciókat. Bár Irán számára a szankciós büntetés nem volt újjonság (és ennek az iráni vezetók azóta is sokszor hangot adtak), a tény, hogy azokat az ENSZ BT hozta, sokkolta a helyi elitet és közvéleményt. Az ENSZ BT határozatai a tartalmukban egyre szigorúbbak lettek, azonban csak az utolsó (1929/2010. jún. 9.) volt az, amelyik a bankrendszert és az olajexportot célozva komoly hatást fejtett ki az iráni gazdaságra. Az ENSZ BT és az Európai Unió mellett több ország is léptetett hatályba szankciókat Iránnal szemben. Bár túlzás lenne azt állítani, hogy Teherán pusztán azok miatt kezdett el tárgyalni a nukleáris megállapodásról, az tény, hogy azoknak is szerepüik volt benne.

A nukleáris megállapodás megkötésében az Egyesült Államokban és Iránban bekövetkezett politikai vezetőváltás is fontos momentum volt. A Barack Obama vezette adminisztráció, amely 2009-ben lépett hivatalba, egyértelművé tette, hogy a nukleáris kérdés megoldását a tárgyalásos megközelítésben látja („kinyújtott kéz”). Iránban - szintén 2009-től - ismét Mahmúd Ahmadinezsád lett ugyan az elnök, de a választás előtti vita és küiönösen az azt követő demonstrációk a velájat-e faqih a vallástudós irányításának a legitimációját és fenntartását is veszélyeztette (N. Rózsa, 2020). Ugyanakkor az Irán elleni nukleáris szankciók a nemzetközi közösségben is nézeteltérésekhez 


\section{Külïgyi Szemle}

vezettek, úgy az ENSZ BT állandó tagjai, mint más országok között. Különösen a „fejlődő” világ államai vélték úgy, hogy a fejlett országok - köztük éppen az atomhatalmak is - a „kettős mércéjuikkel” nemcsak a fejlett technológia elsajátítását kívánják másoktól megtagadni, hanem éppen egy olyan vélelmezett katonai fejlesztés lehetőségéért kívánnak egy államot megbüntetni, amellyel ők maguk is rendelkeznek.

Így amikor 2015. július 14-én az E3/EU+3 (azaz az Egyesült Álla mok, Nagy-Britannia, Franciaország, Oroszország, Kína és Németor szág) ${ }^{12}$ képviseletében Federica Mogherini, az EU kül- és biztonságpo litikai főképviselője, valamint Mohamed Dzsavád Zarif iráni külügy miniszter bejelentette, hogy megszüiletett az átfogó megállapodás az iráni nukleáris programról, a világ legtöbb országa üdvözölte azt.

„Obama elsô nyilatkozatában jó megállapodásról beszélt, mely mindkét utat elvágja Irán előtt a nukleáris fegyverek irányába, egyidejúleg egy éven túlra tolja ki azt az idószakot, melyre Iránnak szüiksége lenne, ha mégis nukleáris fegyvereket akar na előállítani. Zarif történelmi megállapodást emlegetett (The White House, 2015). John Kerry amerikai külügyminiszter elindult a térségbe, hogy a szövetségeseket megnyerje a megállapodásnak. Egyiptom és a Perzsa-öböl arab monarchiái, úgy tűnt, elfogadják azt, különösen, hogy az Egyesült Államok komoly katonai támogatást is ígért (Washington Post, 2015)."

Az Obama-kormányzat pozitív, megnyerő kampánya mellett azon ban - burkoltan vagy nyíltan - a kezdetektől egy ellenkampány is zaj lott: az amerikai törvényhozásban sokan ellenezték a megállapodást, így az nem került a kongresszus elé jóváhagyásra, hanem Obama elnöki rendelettel hirdette ki. A nemzetközi közösségben Benjamin Netanjahu izraeli miniszterelnök folyamatosan a megállapodás ellen tiltakozott, és hamarosan - az amerikai ígéretek ellenére - a Perzsaöböl több arab állama is az ellenzőkhöz csatlakozott.

„Maga a megállapodás egy mintegy nyolcvanoldalas, erősen mú szaki tartalmú szöveg, melyhez öt függeléket csatoltak. Ezekben

12 Ezt a tárgyalási formációt a globális szakirodalom inkább a „P5+1 és Irán” alakban emlegeti. 
a civil nukleáris együttmúködés részleteiről, egy, a vitás kérdések rendezésére felállítandó közös bizottságról van szó, és rögzítették a szerződés megvalósításának menetrendjét is. A 2. számú mel léklet pedig részletesen tartalmazza a részt vevő felek kötelezett ségeit.

A megállapodás mind az urán-, mind a plutóniumutat elvágta Irán elôtt - 10, 15 és 25 éves idôszakokban szabva meg a tiltás terjedelmét. Mivel Irán rendelkezik uránbányákkal, konverziós üzemmel és Natanzban, illetve Fordóban urándúsító üzemekkel, a megállapodás egy jelentős része ezekre fókuszált. A becslések szerint a megállapodás idején Irán mintegy tízezer kilogramm alacsony dúsítású uránnal rendelkezett, ami - ha tovább dúsították volna - 8-10 atombomba elóállításához lett volna elegendő. A megállapodás a következő 10 évben maximum 300 kilogrammot engedélyezett, [azzal, hogy] a fölösleget kiviszik az országból. Az urándúsítás szintjét a következő 15 évre 3,67\%-ban maximálták. A 19 ezer centrifuga számát 6104-re kell csökkenteni a következő 10 évre, és ezek csak Natanzban működhetnek, és ezek is csak az első generációs IR-1-es típusúak lehetnek. A többletet, illetve az ennél fejlettebb típusokat a Nemzetközi Atomenergia Ügynökség (Sic!) ellenőreinek felüigyelete alatt raktárban őrzik. A Fordót átalakítják kutatási és fejlesztési célokra. Fokozott figyelem irányul az újrafeldolgozásra, illetve a tervezett plutónium fütőanyagú araki nehézvízmúves reaktorra, melyet újra kell tervezni. Irán a következő 15 évben nem építhet új nehézvízműves reaktort, és az innen származó kiégett fütőelemeket (időkorlát nélkül örökre) külföldre kell, hogy szállítsa újprafeldolgozásra.

A megállapodás értelmében Irán (ismét) aláirta és vállalta, hogy 25 évig alkalmazni fogja az atomsorompó-szerződés Kiegészitő jegyzőkönyvét. Emellett alkalmazza a NAÜ-vel kötött biztosítéki megállapodásoknak a 3.1 kiegészitését, amely szerint már a tervezési fázisban jelezni kell az Ửgynökség felé, ha egy állam új nukleáris létesítmény építését tervezi. A NAÜ ellenőrei ezen túl bármely létesítményt ellenőrizhetnek, még az ez idáig hozzáférhetetlen katonai létesítményeket is, egy kompromisszumos megállapodás 


\section{Külïgyi Szemle}

értelmében. Az ellenőrzések részleteit a NAÜ főigazgatója, Yukiya Amano és Irán közötti különmegállapodás tartalmazta, konkrét menetrenddel (Amano, 2015). A megállapodás bizonyos vitás (vi tára lehetőséget adó) kérdéseket mégis hagyott maga után, első sorban a szankciók felfüiggesztésével, az ún. "sunsek feltételekkel (azaz, hogy mi lesz a megállapodásban meghatározott 10-15-25 év múlva), illetve az ún. »lehetséges katonai vonatkozásokkak (PMD) kapcsolatban."

\section{A nukleáris megállapodás után ${ }^{13}$}

Az iráni nukleáris megállapodás 2016. január 16-án lépett a megva lósítás szakaszába, és 2018. május 8-ig tulajdonképpen zavartalanul múködött, annak ellenére is, hogy az Egyesült Államokban Donald Trump kerüilt az elnöki székbe, aki kezdettől fogva hangosan ellenezte azt. Az ellenzők érvelésének középpontjában egyrészt magának a megállapodásnak a ténye, másrészt a már említett „sunsel” feltételek álltak. További kritika tárgyát képezte, „hogy a megállapodás nem fog lalkozott olyan kérdésekkel, mint Irán regionális tevékenysége, a ter rorizmus támogatása (Ablaka, 2021), a rakétaprogram vagy az emberi jogok kérdése”, s „mindössze” a nukleáris programra fókuszált. Obama megközelítésében viszont „a nukleáris megállapodás sikeres végrehajtása megteremtheti azt a kezdeti bizalmi tókét, amire építve a többi kérdés is tárgyalhatóvá válik".

„Donald Trump hivatalba lépése után utasítást adott az Irán-politika felülvizsgálatára, és bár két alkalommal még hajlandó volt nyilat kozatot tenni arról, hogy Irán betartja a megállapodásban foglaltakat, egyre nyilvánvalóbb volt, hogy eljön a pillanat, amikor ezt nem fogja megtenni. 2018. május 8-án végüil bejelentette, hogy az Egyesült Államok kilép a nukleáris megállapodásból.

A bejelentést intenzív diplomáciai tevékenység előzte meg: az Európai Unió, továbbá az Iránnal korábban tárgyaló három európai állam vezetői (Theresa May brit miniszterelnök, Emmanuel Macron francia elnök és Angela Merkel német kancellár)

13 A fejezet a szerző nemrég megjelent tanulmányán alapul. Ld. N. Rózsa, 2021. 
személyes találkozókon (is) igyekeztek Trumpot meggyőzni arról, hogy ne mondja fel a megállapodást. Macron még egy olyan tervet is előterjesztett, melyben kiegészítéseket fogalmaztak volna meg a megállapodáshoz a legérzékenyebbnek vélt rakétaprogram kérdé sében. Jóllehet kérdéses volt, hogy az iráni vezetők hogyan viszo nyulnának a megállapodás ily módon történő kiegészítéséhez, erre már nem került sor.

Trump elképzelése szerint egy átfogó, minden kérdésre kitérő megállapodásra kell az irániakat rákényszeríteni, azonban ebbe az irányba nem történtek lépések. 2018. július végén azonban váratlanul Trump elnök bejelentette, hogy hajlandó találkozni »bármikor ... előfeltételek nélküik az iráni vezetőkkel. Ugyanakkor Mike Pompeo külügyminiszter tizenkét pontban sorolta fel a feltételeket, Irán azonban visszautasította az »ajánlatot «: "Irán nem Észak-Korea..." (The Guardian, 2018)."

„Az Egyesült Államok 2018 augusztusában visszaállította az Irán nal szembeni szankciók egy részét, és nyilvánvalóvá tette, hogy a külföldi nagyvállalatok sem kaphatnak felmentést a [másodlagos] szankciók alól. ${ }^{14}$ A bankokra és az olajexportra vonatkozó szankciókat 2018. november 4-én állították vissza. (A dátumnak szim bolikus jelentősége volt, hiszen 1979-ben iszlám forradalmi diákok egy csoportja ezen a napon foglalta el a teheráni amerikai nagykövetséget.) Donald Trump [a maximum pressure jelszavával] a teljes iráni olajexportot kívánta megakadályozni, amivel igen nagy felzúdulást váltott ki a világban. Az Európai Unió igen nehéz helyzetbe került: miközben morális felelősséget érzett a megállapodásért, és politikai hitelessége (is) függött a megállapodás túlélésétől, az európai politikai vezetők határozott kiállása ellenére az európai nagyvállalatok sorban jelentették be, hogy kivonulnak Iránból (vagy még be sem vonultak). Az utolsó pillanatban Trump ugyan további hat hónapra elnöki felmentést adott nyolc országnak (Kína, India, Dél-Korea, Törökország, Olaszország, az Egyesüllt Arab Emirátusok,

14 Meg kell jegyezni, hogy az Egyesült Államokban az iráni szankciós törvény végig az Obama-kormányzat hivatali ideje alatt is - hatályban maradt. 


\section{Külïgyi Szemle}

Japán, Tajvan), hogy iráni olajat szerezhessenek be az amerikai szankciók terhe nélkül, azonban ennek lejártakor a szankciók ezen országok számára is végleg hatályba léptek.

Irán igen nehéz helyzetbe került, hiszen miközben tartotta magát a megállapodásban foglaltakhoz - amit a NAÜ rendszeresen igazolt, a felmerülő néhány vitás kérdést pedig a Bécsben hathavonta összeülő Közös Bizottság tárgyalta és rendezte -, a trumpi »maximális nyomás politika hatásosabban zárta el Iránt, mint az ENSZ BT korábbi szankciói. Közben a társadalmi elégedetlenség is egyre nőtt, mivel a megállapodástól várt gazdasági előnyök nem teljesültek. A munkanélküiliség, melynek kezelése Rouháni újraválasztási kampányának egyik fó ígérete volt, jelentősen nem csökkent (12\%ról 11\%-ra), és 2017 végén több iráni városban is tüntetésekre került sor, amiben a nyugati sajtó és egyes politikusok rögtön a velájet-e faqih végét látták. Azonban a tüntetések kicsik és szétszórtak voltak, és a rend fenntartásához a helyi rendőri erők elegendőnek bizonyultak."

\section{Stratégiai tuirelem és nyomásgyakorlás-keresés ${ }^{15}$}

Irán 2018. május 8-tól 2019. május 8-ig „stratégiai türelmet” gyakorolt: egyrészt, hogy megmutassa a világnak, ô a maga részéről betartja a megállapodást. Másrészt idôt akart hagyni a megállapodásban részes többi félnek, illetve harmadik országoknak, hogy az amerikai szankciók ellenére teljesítsék vállalt kötelezettségeiket. Bár a legtöbb állam megpróbált kikerülő megoldásokat találni - az orosz, kínai, indiai re lációban a saját valutában történő elszámolásra próbáltak áttérni, míg az Európai Unió a humanitárius forgalomra korlátozott ún. INSTEX mechanizmust vezette be és próbálta múködtetni -, valójában egyik sem vezetett sikerre.

Így a stratégiai türelem éve lejártával Irán kétirányú politikába kezdett: egyrészt abból kiindulva, hogy a nemzetközi közösség, de fő leg az Európai Unió számára a megállapodás fegyverzet-ellenőrzési

15 A fejezet részlet a szerző idézett múvéből: N. Rózsa, 2021. 
és nonproliferációs tartalma prioritás, Irán előre bejelentett és dokumentált módon, több lépcsőben „lépett hátra” a megállapodásban foglalt kötelezettségek teljesítésétől, miközben magából a megállapodásból máig nem lépett ki. Minden bejelentés részét képezte, hogy a lépések visszafordíthatók.

Másrészt Irán meg akarta mutatni a nemzetközi közösségnek, hogy ha a Perzsa-öbölben fegyveres konfliktus alakul ki, az az egész világra nézve következményekkel jár. Ennek a „megmutatásnak” a formája olyan alacsony intenzitású, de az eszkaláció potenciális lehetőségét magában hordozó támadások sorozata volt, melyet sem a térség országai, sem az Egyesült Államok nem hagyhatott figyelmen kívül és válasz nélkül. Ebben az adok-kapokban azonban minden fél igen óvatosan járt el, bár voltak olyan elképzelések, hogy Izrael és Szaúd-Arábia kifejezetten örülne, ha az Egyesült Államok megtámadná Iránt. Irán azonban nagyon óvatosan számította ki [az] akcióit és válaszlépéseit, és [bár] egyszer Trump elnök mindössze néhány perceel az Irán elleni támadás megkezdése előtt vonta vissza [a] parancsát (Ward, 2019), a nyílt háborút sikerült elkerülni. Irán akciói elsősorban a Perzsa-öböl olajforgalmának korlátozására irányultak. A legjelentősebb egy szaúdi olajmezőt és olajfinomítót ért. Bár máig nem bizonyított, hogy ezt a támadást Irán, Iránnal szövetséges valamely csoport vagy valaki más követte-e el, az esemény illeszkedik az iráni támadás sorozatba, jóllehet az egyszerú tankerfoglaláshoz képest határozott kategóriaváltást jelentett. Üzenete világos volt: Irán képes nagy precizitással elérni ellenfelei stratégiai érdekeit. A következmény: az Egyesült Arab Emírségek delegációja néhány napon belül Teheránban járt tárgyalni, de Szaúd-Arábia is megpróbált valamiféle csatornát kiépíteni az iráni vezetés felé. Sőt, Kászem Szolejmáni - az iraki miniszterelnök bejelentése szerint - éppen egy szaúdi-iráni közvetítő misszióban járt, amikor likvidálták ${ }^{16}$ (Independent, 2020).

16 „Úgy volt, hogy aznap reggel találkozom vele, amikor megölték; azért jött, hogy választ hozzon Iránból egy olyan üzenetre, amelyet mi közvetítettünk a szaúdiak tól Iránnak" - mondta Ádil Abdul-Mahdi iraki miniszterelnök. 


\section{Külïgyi Szemle}

Mindezek - Trump bejelentése, hogy a támadás megkezdése előtt néhány perceel leállította azt; a szaúdi olajfinomító és olajmező elleni támadás - jelentős következményekkel jártak a Perzsa-öböl és az egész Közel-Kelet biztonságára: az Egyesült Államok hitele, hogy megvédi [a] szövetségeseit, megingott. Ennek hatására a térség államai egyrészt más külső hatalmakhoz (Oroszország, Kína) kezdtek közeledni, másrészt megindult a gondolkodás, hogyan tudnának saját maguk gondoskodni [a] biztonságukról. Ez további fegyverbeszerzésekhez, a fegyverkezési verseny fokozásához, továbbá a Perzsa-öbölben felállítandó biztonsági rendszerről folytatandó tárgyalások felújításához vezet(het).

\section{Joe Biden és Ebrahim Raiszi - az amerikai-iráni nukleáris tárgyalások kérdôjelei}

A 2021-es év újabb fordulatokat és a megegyezés lehetőségét hozta: 2021 januárjában beiktatták hivatalába Joe Biden amerikai elnököt, aki a választási kampányában a nukleáris megállapodáshoz történő amerikai visszatérést hirdette. Augusztusban pedig Iránban Ebrahim Raiszi kezdte meg az elnökségét, aki a legkonzervatívabb vallási körökből érkezett.

A Biden-kormányzat külpolitikai csapatának vezető tagjai (Antony Blinken, Nicholas Burns, Jake Sullivan, Wendy Sherman, Robert Malley és mások) korábban Obama külpolitikai teamjében dolgoztak, többségüik a közel-keleti, sőt az Iránnal kapcsolatos ügyekben is komoly tapasztalatokkal rendelkezik - miközben Obama elnökhelyetteseként maga Biden is jelentős külpolitikai tapasztalatokra tett szert. Azonban ma sem a Közel-Kelet, sem Irán nem szerepel az Egyesült Államok külpolitikai prioritásai között, ráadásul mivel „,a Bidenkormányzat tevékenységét nem az iráni atomalkuhoz való visszatérés alapján fogják megitélni, hiszen olyan kihívásokkal kell szembenéznie, mint Kína térnyerése, a globális felmelegedés vagy az ismét erősödő migráció kezelése, Bidenék várhatóan egyfajta kockázatkezeló-háritó politikát folytatnak majd" a kérdésben. Ugyanakkor azzal is tisztában 
vannak, hogy bár „nem Irán az Egyesült Államok legnagyobb problé mája..., de az egyetlen, amely olyan regionális konfliktus kibontakozásával fenyeget, amely [adott esetben] szüikségessé teheti/kikényszerítheti az Egyesült Államok katonai beavatkozását" (Miller, 2021).

A tanulmány írásakor még zajlik a Raiszi-kormány felállítása - a többlépcsős folyamatban az elnök javaslatot tesz a miniszterek személyére, akiknek a jelölését a parlamentnek is jóvá kell hagynia -, de úgy tûnik, hogy az ultrakonzervatívnak tartott Hoszein Amir Abdolláhiján küilügyminiszter mellett a helyettese, Abbász Araghcsi, az eddigi tár gyalócsapat vezetője továbbra is a helyén marad. A nukleáris kérdések rôl folyó egyeztetések szempontjából Iránnak is fontos a folytonosság és a tárgyalási tapasztalat, ugyanis számára a megállapodásnak nincs alternatívája. A szankciók, küilönösen a Donald Trump által bevezetett és betartatott szankciók, a külföldi partnerek megjelenésének az elma radása, a gazdasági helyzet stagnálása - „az ellenállási gazdaság” viszonylagos sikere ellenére (N. Rózsa és Szigetvári, 2019) -, valamint az Iránt egyre jobban sújtó szárazság és elsivatagosodás, az abból adódó vízproblémák (Szálkai és Szabó, 2021), illetve az egyelőre megfékezhetetlen Covid19-járvány olyan belpolitikai helyzetet teremtettek, hogy - a rendszer fenntartása érdekében - az iráni vezetésnek a nukleáris program kérdésében meg kell állapodnia a nemzetközi közösséggel, elsősorban az Egyesüilt Államokkal. Raiszi a beiktatását követően azt hangsúlyozta, hogy „az Irán népe elleni szankciókat fel kell oldani... minden diplomáciai tervet, amely erre az eredményre vezet, támogatni fogunk" (ISNA, 2021). Az iráni politika következetes: a nukleáris megállapodáshoz való visszatérés egyrészt annak a teljes egészét jelenti, azaz mindenkinek minden kötelezettségét vállalnia és teljesítenie kell; másrészt csak és kizárólag a nukleáris programról szólhatnak a tárgyalások, új témát (legalábbis ebbe a keretbe) nem lehet bevonni.

Tehát úgy tűnik, hogy bár mindkét fél - azaz a tárgyalások mul tilaterális jellege ellenére a megállapodáshoz feltétlenül szükséges partnerek, az Egyesült Államok és Irán - érdekelt az atomalkuhoz való visszatérésben és a konfliktus esetleges eszkalációjának az elkerülésében, ez nem is olyan egyszerú. Miközben az iráni oldalon a visszatérés lehetőségét elvileg minden politikai erő - bár küiönböző 


\section{Külïgyi Szemle}

feltételek mellett - támogatja, az amerikai belpolitikában annak sok ellenzője van, még Biden saját pártján belül is. Nem véletlen, hogy a Biden-adminisztráció hivatalba lépése után hónapokig nem tör tént előrelépés a kampányígéret (a nukleáris megállapodáshoz való visszatérés) kérdésében. A 2021. június 18-án tartott iráni elnökválasztás, illetve az augusztus 5-ére kitűzött elnöki beiktatás azonban egyfajta időkényszert eredményezett, így április és június között Bécsben a nukleáris tárgyalások hat fordulójára került sor. Miközben a hírek komoly haladásról számoltak be, mind az Egyesüilt Államok, mind Irán igyekezett a saját tárgyalópozícióját erősítő stratégiai előnyökhöz jutni.

Irán részéről - különösen Washingtonnak a Khamenei ajatollah által az amerikai megbízhatatlanság újabb jeleként értékelt késlekedése láttán - tovább folytatódott, sôt újabb szintekre lépett a 2019 től gyakorolt kettôs politika (a nukleáris megállapodásokban foglaltak végre nem hajtása, illetve a támadások). A technológiai továbblépések Irán részéről olyan képességek megszerzését jelezték, amelyek egyértelműen a nukleáris megállapodás korlátozása alá estek: növelték az uráncentrifugák számát, egyre fejlettebb típusokat állítottak be, végül uránfémet is előállítottak (AP, 2021). Áprilisban Irán már 60 százalékos dúsítottságú uránt állított elő (The New York Times, 2021), júliusban pedig Haszan Rouháni távozó el nök bejelentette, hogy az ország 90 százalékos dúsítottságú urán előállítására is képes, ha szükséges - ami fegyverminőségű uránnak számít. Azonban hozzátette, hogy „mindent meg tudunk valósítani a békés úton”. ${ }^{17}$ Általános, bár nem teljes körủ vélemény szerint Irán továbbra sem kíván nukleáris fegyvereket fejleszteni - ezt Raiszi a beiktatási beszédében ismét megerősítette: „az iráni program teljes egészében békés, és az Iszlám Köztársaság - a legfőbb vezető fatvájának megfelelően - a nukleáris fegyvereket tilosnak ismeri el [tudja/tartja], és Irán védelmi doktrínájában ennek a fegyvernek nines helye" (ISNA, 2021).

17 ., Even if one day there is a need for 90 percent enrichment for a reactor, we do not have any problem and we are able, Rouhani said, according to the IRNA, a state-run news agency. "We can do anything in the peaceful path." (Strozewski, 2021). 
Ugyanakkor újabb és újabb Iránnak (vagy vele kapcsolatban álló csoportoknak) tulajdonított támadások történtek olajszállítók ellen a Perzsa-öbölben - a legutóbb július végén, az ománi vizeken hajózó Mercer Street tanker ellen -, amelyeket Teherán a tárgyalási pozíciója megerősítésére szeretne használni. A szankciók feloldása mellett Irán garanciát akar kapni arra is, hogy a megállapodásból való amerikai kilépés nem történik meg még egyszer - azonban ezt a feltételt az amerikai tárgyalók egyelőre elutasították.

Az Egyesült Államok részérôl egyrészt a térségbeli szövetségesek érdekeinek a védelme, másrészt az azokat fenyegető iráni programok (rakétaprogram, Irán regionális tevékenysége) állnak a figyelem középpontjában. Miközben a Biden-kormányzat is a megállapodás kiszélesítésére törekedne, különös nyomást jelent számára a Naftali Bennett vezette, az Irán-kérdésben a Netanjahu-kormánnyal folytonosságot mutató új izraeli kabinet politikája. Benny Gantz védelmi miniszter szerint Irán „tíz hétre van attól, hogy fegyverminőségủ uránhoz jusson" (The Jerusalem Post, 2021). Sỏt, az utóbbi években egyre gyakoribbá váló kibertámadások mellett - 2012 óta először ismét egy esetleges katonai támadás terveiről jönnek hírek Izraelből. A Közel-Kelet és Irán azonban ennek ellenére sem szerepel a Bidenkormányzat legfontosabb prioritásai között.

\section{Konklúzió}

E tanulmány írásakor még nem lehet tudni, hogy a tárgyaló felek mikor térnek vissza Bécsbe, illetve visszatérnek-e a megállapodásban foglaltak betartásához. Sokak szerint a helyzet 2015 óta jelentősen megváltozott: Irán olyan tudásra, tapasztalatra tett szert, amellyel akkor még nem rendelkezett, ugyanakkor a saját programjának - akár az urándúsítás mértékének, akár az uráncentrifugák számának és minőségének - a korlátozásában van már tapasztalata. Azonban mivel a nukleáris szankciók egy komplex, soktényezós szankciós rendszer ré szét képezik, a feloldásuk önmagában nem oldja meg az ország problémáit, pedig úgy tủnik, az iráni gazdaság mégiscsak talpon maradt 


\section{Külïgyi Szemle}

(Forián-Szabó és Kovács, 2021). Ugyanakkor a járványhelyzet és a kör nyezeti katasztrófák az iráni vezetés számára egyfajta megegyezési kényszert eredményeznek; ennek egyik jele, hogy Khamenei ajatollah meghátrálni látszik a Covid19 elleni nyugati oltások tilalma ügyében.

A nukleáris megállapodásról szóló tárgyalások önmagukban nem nyújtanak kellő biztosítékot a térség más államai, elsősorban Izrael és a Perzsa-öböl egyes arab országai számára, különösen amiatt, hogy az Egyesült Államok egyre kevésbé akar katonailag beavatkozni a térségben. A szíriai, iraki, majd a napokban lezajlott afganisztáni kivonulás keserú tapasztalat a térségbeli amerikai szövetségesek számára: azt üzeni, hogy itt az ideje, hogy maguk gondoskodjanak a saját biztonságukról. Ebben a pillanatban tehát nem tűnik lehetetlennek, hogy a Perzsa-öböl országai között meginduló - látható és a háttérben folyó - konzultációk megvessék az alapjait egy már régóta tervezett, de máig meg nem valósult regionális biztonsági struktúrának. Ez egyrészt előrelépést jelenthetne az iráni és más rakétaprogramok és egyéb regionális törekvések korlátozása felé, másrészt teljesítené azt az évtizedes iráni követelést és stratégiai célt, hogy a térség biztonságát az ott fekvő országok felüigyeljék.

\section{I rodalomjegyzék}

Ablaka Gergely (2021). Transznacionális Irán. Nem állami szereplók a KözelKeleten - militáns partnerek Teherán „szolgálatában”. Külügyi Szemle, 20(3), 113-144.

Academic Peace Orchestra Middle East (2016). A letöltés ideje: 2021. augusztus 10. http://academicpeaceorchestra.com/.

Csicsmann, László (2021). A szankciók mint a nyomásgyakorlás eszközei a nemzetközi kapcsolatokban: a Közel-Kelet és Irán esete. Küliugyi Szemle, $20(3), 80-112$.

Csicsmann László, N. Rózsa Erzsébet és Szalai Máté (2017). The MENA Region in the Global Order: Actors, Contentious Issues and Integration Dynamics. MENARA Methodology and Concept Papers, (4). A letöltés ideje: 2021. szeptember 5. http://menaraproject.eu/wp-content/ uploads $/ 2017 / 11 /$ menara_cp_4.pdf. 
Fórián-Szabó Viktor és Kovács Tamás (2021). Terhelő örökség. Az iráni gazdaság lehetőségei és kihívásai a 2021-es elnökválasztás után. Külügyi Szemle, 20(3), 38-79.

Gladstone, Rick, Broad, William J. és Crowley, Michael (2021). Iran Says It Began Enriching Uranium to 60 Percent. How Important Is That? The New York Times. A letöltés ideje: 2021. szeptember 6. https:// www.nvtimes.com/2021/04/16/world/middleeast/iran-nuclear-talksuranium-explainer.html.

Harkov, Lahav és Lazaroff, Tovah (2021). Gantz: Iran Is 10 Weeks from Breakout to A Nuclear Weapon. The Jerusalem Post. A letöltés ideje: 2021. szeptember 6. https://www.jpost.com/israel-news/israel-to-unsehalt-irans-brazen-ship-attacks-675793.

IAEA (2015). IAEA Director General's Statement and Road-map for the Clarification of Past and Present Outstanding Issues Regarding Iran's Nuclear Programme. A letöltés ideje: 2021. szeptember 5. https://www. iaea.org/newscenter/statements/iaea-director-generals-statementand-road-map-for-the-clarification-of-past-present-outstandingissues-regarding-irans-nuclear-programme.

IAEAPRIS (2021). Power Reactor Information System. A letöltés ideje: 2021. augusztus 10. https:/pris.iaea.org/.

International Atomic Energy Agency (2021). Nuclear Power Reactors in the World. IAEA. A letöltés ideje: 2021. augusztus 10. https://www-pub.iaea. org/MTCD/Publications/PDF/RDS-2-41_web.pdf.

ISNA (2021). Raiszi: az har tarh-e diplomatik ke báesz-e laghv-e tahrimhá savad esztekbál mikonim [Minden diplomáciai tervet. mely a szankciók eltörlését okozza, elfogadunk]. A letöltés ideje: 2021. szeptember 6. https:/www.isna.ir/news/1400051410194/\%D8\%Bl\%D8 $\%$ A6\%DB $\% 8 \mathrm{C} \% \mathrm{D} 8 \% \mathrm{~B} 3 \% \mathrm{DB} \% 8 \mathrm{C}-\% \mathrm{D} 8 \% \mathrm{~A} 7 \% \mathrm{D} 8 \% \mathrm{~B} 2-\% \mathrm{D} 9 \% 87 \% \mathrm{D} 8 \mathrm{B1}$ \% $8 \%$ B 7\% D 8\%B1\%D 8\%AD-\%D 8\%AF\%DB\% 8C \%D 9\%BE \% $9 \% 84$ \% $9 \% 85 \% \mathrm{D} 8 \%$ A7\% D $8 \%$ AA\%DB\% $8 \mathrm{C} \% \mathrm{DA} \% \mathrm{~A} 9-\% \mathrm{DA} \% \mathrm{~A} 9 \% \mathrm{D} 987-$

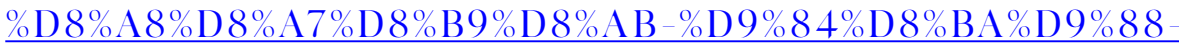
\% $8 \% \mathrm{AA} \% \mathrm{D} 8 \% \mathrm{AD} \% \mathrm{D} 8 \% \mathrm{B1} \% \mathrm{DB} \% 8 \mathrm{C} \% \mathrm{D} 9 \% 85-\% \mathrm{D} 9 \% 87 \% \mathrm{D} 8 \% \mathrm{~A} 7-$

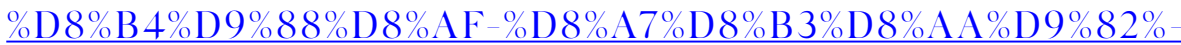
D8\%A8\%D8\%A7\%D9\%84-\%D9\%85\%DB\%8C-\%DA\%A9\%D9\%86\%D9\%85.

Jones, Rodney W., Koblentz, Gregory D., McDonough, Mark G. és Dalton, Toby F. (1998). Tracking Nuclear Proliferation. Washington, D.C.: Carnegie Endowment for International Peace. 


\section{Külïgyi Szemle}

Keesing's World News Archive (1991). A letöltés ideje: 2021. augusztus 10. http://keesings.com/index new.php.

Miller, Aaron (2021). Is Time Running Out for the JCPOA? Webinar organized by the Quincy Institute. YouTube. A letöltés ideje: 2021. szeptember 5. https:/www.voutube.com/watch?v=Wz3JG3SUMZs.

Morello, Carol (2015). On Kerry Visit, Arab Nations Express Support for Iran Nuclear Agreement. The Washington Post. A letöltés ideje: 2021. szeptember 6. https://www.washingtonpost.com/world/middle east/ on-kerrv-visit-arab-nations-express-support-for-iran-nuclearagreement/2015/08/03/36bbebea-36d3-11e5-ab7b-6416d97c73c2 story.html?utm term $=.8716580$ fee 32 .

N. Rózsa Erzsébet (2018). Weapons of Mass Destruction in the Middle East and North Africa. MENARA Working Papers, (24). A letöltés ideje: 2021. szeptember 6. http://menaraproject.eu/wp-content/uploads/2018/11/ menara wp 24.pdf.

N. Rózsa Erzsébet (2020). Hagyomány és modernilás. Az iráni külpolitika kihivásai a 21. szäzad elején. Budapest: Nemzeti Közszolgálati Egyetem Közigazgatási Továbbképzési Intézet.

N. Rózsa Erzsébet (2021). Az iráni nukleáris program kihívása a Biden elnökség kezdetén. In Kajtár Gábor (szerk.), A nemzelközi jog, az uniósjog és a nemzetközi kapcsolatok szerepe a 21. században. Tanulmányok Valki László liszlelelére (731-748. o.).

N. Rózsa Erzsébet és Péczeli Anna (2013). Az atomfegyvermentes övezetek. In N. Rózsa Erzsébet és Péczeli Anna (szerk.), Egy békésebb világ eszközei. Fegyverzelellenôrzés, leszerelés, non-proliferáció (147-163. o.).

N. Rózsa Erzsébet és Szigetvári Tamás (2019). The Resistance Economy: Iranian Patriotism and Economic Liberalisation. In Gerőcs Tamás és Szanyi Miklós (szerk.), Market Liberalism and Economic Palriolism in the Capilalist World-System (169-182. o.)

Pleitgen, Frederik, Otto Claudia és Mostaghim, Ramin (2021). Iran's Hardline New President Sworn in Amid Stalled Nuclear Talks and Hopes of Saudi Detente. CNN. A letöltés ideje: 2021. szeptember 6. https:/edition.cnn. com/2021/08/05/middleeast/iran-president-raisi-inauguration-intl/ index.html.

Rising, David (2021). UN Nuclear Watchdog: Iran Producing More Uranium Metal. AP News. A letöltés ideje: 2021. szeptember 5. https:/apnews. com/article/joe-biden-middle-east-business-europe-iran-nuclear$468969423 \mathrm{ed} 42240 \mathrm{aOcb647ad5987617.}$ 
Sengupta, Kim (2020). The Reason Qassem Soleimani Was in Baghdad Shows How Complex the Iran Crisis Is. Independent. A letöltés ideje: 2021. szeptember 6. https://www.independent.co.uk/voices/ qassem-soleimani-death-iran-baghdad-middle-east-iraq-saudiarabia-a9272901.html.

Space Daily (2010). Ahmadinejad Promises 'Global' Response if Iran Is Attacked. A letöltés ideje: 2010. augusztus 21. http://www.spacedailv. $\mathrm{com} / \mathrm{reports} / \mathrm{Ahmadinejad}$ promises global response if Iran is attacked 999.html.

Staff and Agencies (2018). Trump Offer to Meet Iran President Rouhani Dismissed by Both Sides. The Guardian. A letöltés ideje: 2021. szeptember 5. https://www.theguardian.com/us-news/2018/jul/31/trump-offer-tomeet-iran-president-rouhani-dismissed-by-both-sides.

Strozewski, Zoe (2021). Iran President Rouhani Tells Cabinet Nation Is Capable of Enriching Uranium to 90 Percent. Newsweek. A letöltés ideje: 2021. szeptember 6. https://www.newsweek.com/iranpresident-hassan-rouhani-tells-cabinet-nation-capable-enrichinguranium-90-1609633.

Szálkai Kinga és Szabó Miklós (2021). Az iráni vízválság a klímaváltozás és a növekvő társadalmi elégedetlenség árnyékában. Kïlügyi Szemle, 20(3), $5-37$.

The While House (2015). The Historic Deal that Will Prevent Iran from Acquiring a Nuclear Weapon. A letöltés ideje: 2021. szeptember 6. https:/obamawhitehouse.archives.gov/issues/foreign-policv/iran-deal.

Ward, Alex (2019). Trump Confirms He Called off a Military Strike on Iran. Vox. A letöltés ideje: 2021. szeptember 5. https:/www.vox. com/2019/6/21/18700570/trump-iran-attack-drone-twitter.

World Nuclear Association (2021). Nuclear Power in Iran. A letöltés ideje: 2021. augusztus 10. https://www.world-nuclear.org/information-librarv/ country-profiles/countries-g-n/iran.aspx. 